\title{
Biosensors for Contaminants Monitoring in Food and Environment for Human and Environmental Health
}

\author{
Lívia Maria da Costa Silva, \\ Vânia Paula Salviano dos Santos, \\ Andrea Medeiros Salgado and Karen Signori Pereira
}

Additional information is available at the end of the chapter

http://dx.doi.org/10.5772/55617

\section{Introduction}

Environmental security is one of the fundamental requirements of our well-being. However, it still remains a major global challenge, on account of the increasing number of potentially harmful pollutants (chemical compounds, toxins and pathogens) discharges into the environment [1]. In this context, the detection and monitoring of environmental pollutants in soil, water and air is very important in the overall safety and security of humans, other animals and plants.

The requirements for application of most traditional analytical methods to environmental pollutants analysis often constitute an important impediment for their application on a regular basis. These analysis calls for fast and cost-effective analytical techniques to be used in extensive monitoring programs. So, the need for disposable systems or tools for environmental applications has encouraged the development of new technologies and more suitable methodologies. In this context, biosensors appear as a suitable alternative or as a complementary analytical tool. Biosensors can be considered as a subgroup of chemical sensors in which a biological mechanism is used for analyte detection [2,3,4].

A biosensor (Figure 1) is defined by the International Union of Pure and Applied Chemistry (IUPAC) as a self-contained integrated device that is capable of providing specific quantitative or semi-quantitative analytical information using a biological recognition element (biochemical receptor), which is retained in contact direct spatial with a transduction element [5]. 


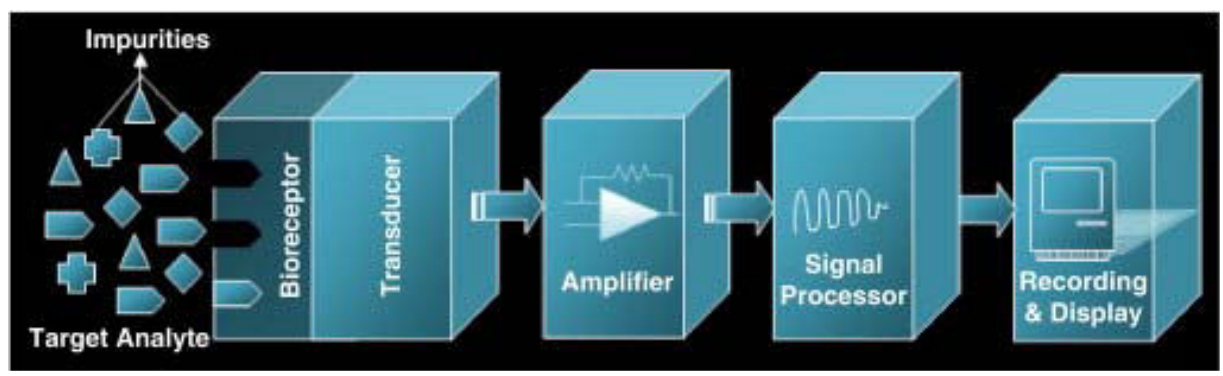

Figure 1. Biosensor scheme [6].

Based on the principle of specific biological-recognition measurements coupled with a signal transducer, biosensor technologies have developed over the past several decades, resulting in commercial production of versatile and portable instruments for many applications that greatly impacts the bioprocess control, food quality control, agriculture, environment, military and mainly medicine and clinical analysis. Overall, there are three so-called generations of biosensors: first generation biosensors operates on electrical response, second generation biosensors function involving specific mediators between the reaction and the transducer for generation of a improved response, and in third generation biosensors the reaction itself causes the response and no product or mediator diffusion is directly involved [7].

In the 21st century, with the progression in the sciences, nanobiosensors with superbly dedicated miniature sensors with highly miniaturization were developed. In this context, nanomaterials transducer modification and genetic engineering of the biocomponents are the main strategies to overcome the reported drawbacks of low sensitivity and reusability/ regeneration of working electrode $[7,8]$.

The main classes of bioreceptor elements that are applied in environmental analysis are microbial whole-cell, enzymes, antibodies and DNA. Additionally, electrochemical transducers are used in most of the biosensors described in the literature for environmental applications [5]. In recent years, the number of investigations on biosensors has been very high, which reflects the considerable interest in the theme. Nevertheless, there is a lag between the high level of technological and scientific development and the limited use of these devices in the real environmental and agro-food analysis $[9,10]$.

So, given the applicability of biosensors, this chapter reviews the development and use of some biosensors in the contaminants monitoring in food and environment for human and environmental health, describing the three main areas of application: fertilizers, pesticides and quality and safety of food.

\section{Biosensors for nitrogen compounds and fertilizers determination}

Because nitrogen compounds are pollutant found in several industrial effluents its determination is of extreme importance for the environment. Several methods are used to 
urea determination, including spectrophotometry, fluorimetry, potentiometry and amperometry. But some of these require a pretreatment or are unsuitable for monitoring in situ. For this reason there has been growing interest in the development of biosensors for these determinations.

Urea is a nitrogen compound widely used, such as fertilizer in agriculture and as a nitrogen source for animal feeding stuff additive. The determination of urea is of great importance in areas such as clinical analysis, food industry, cosmetics and environmental assessment. In the environmental area, the large amount of urea in wastewater and water bodies can encourage the eutrophication process.

In this context, the first urea potentiometric biosensor ever made was built by Guilbault and Montalvo [11], and measured urea through its enzyme-catalyzed hydrolysis. This first device was consisted of urease immobilization on polyacrylamide gel on the surface of an ammonium ion-selective electrode. Furthermore, in 1984, Arnold and Glazier [12], developed a urea potentiometric biosensor based on jack bean extract immobilization on the surface of an ammonia gas sensitive electrode. Since then, several instruments were developed and Table 1 shows some biosensors for urea quantification with different transduction system.

Urease is abundant enzyme in plants and, moreover, it can be found at numerous of eukaryotic microorganisms and bacteria. The bacterial and plant ureases have high sequence similarity, suggesting that they have similar three-dimensional structures and a conserved catalytic mechanism. Ureases (urea amidohydrolase, EC 3.5.1.5) catalyzes the hydrolysis of urea to yield ammonia and carbamat, the latter compound decomposes spontaneously to generate a second molecule of ammonia and carbon dioxide [13].

\begin{tabular}{|c|c|c|}
\hline Biological component & Transductor & Reference \\
\hline $\begin{array}{l}\text { Urease immobilized on gelatin beads via cross-linking with } \\
\qquad \text { glutaraldehyde }\end{array}$ & Potentiometry & [14] \\
\hline Urease immobilized on electrosynthesized polymer & Potentiometry & [15] \\
\hline Urease immobilized on air stable lipid films & Optical & [16] \\
\hline $\begin{array}{l}\text { Urease immobilized, through entrapping, onto the ion } \\
\text { sensitive membrane using a polymer matrix of } \\
\text { poly(carbamoylsulphonate) and polyethyleneimine }\end{array}$ & Potentiometry & [17] \\
\hline $\begin{array}{l}\text { Urease immobilized on platinum electrode both by chemical } \\
\text { binding and electropolymerization }\end{array}$ & Conductometry & [18] \\
\hline Urease immobilized on electropolymerized toluidine blue film & Amperometry & [19] \\
\hline $\begin{array}{l}\text { Urease immobilized with sol-gel } \\
\text { approach onto a nylon membrane }\end{array}$ & Colorimetry & [20] \\
\hline
\end{tabular}

Table 1. Biosensors for urea quantification. 
Other nitrogen compounds such as nitrate and nitrite are used in fertilizers. Nitrate is the most ubiquitous chemical contaminant in groundwater and soil. The increasing levels of nitrate found in groundwater and surface water concern because they can harm the aquatic environment. In line with this, the regulations for treatment of urban wastewater in order to reduce pollution, including pollution by nitrates from sewage treatment works of industrial and domestic have been implemented [21]. Spectrophotometric methods for nitrate determination have been developed over the past several decades. Popular methods for nitrate analysis utilize ion-exchange chromatography combined with spectrometric, conductometric or electrochemical detection and are suitable for a wide range of environmental samples [22]. On the other hand, nitrites are widely used for food preservation and for fertilization of soils. However, continuous consumption of these ions can cause serious implications on human health, particularly because it can react irreversibly with hemoglobin [23].

Moorcroft et al. [23] had written a review article on the current strategies employed to facilitate the detection, determination and monitoring of nitrate and/or nitrite presence. This review shows that the increasing demand for rapid on-site analysis will ensure the continued development of both spectroscopic and electrochemical methods, which are more applicable to miniaturization and remote operation. Thereby the biosensors development goes against to the conclusion of Moorcroft et al [23]. Moreover, for the analysis of these compounds, biosensors based on nitrate reductase enzyme have been developed. Truly amperometric enzyme sensors for this nitrogen compounds were first described in 1994. Nitrate reductase (NR) (EC 1.7.1.3) catalyzes $\mathrm{NAD}(\mathrm{P}) \mathrm{H}$ reduction of nitrate to nitrite.

Silveira et al. [24] had developed a non-mediated electrochemical biosensor for nitrite determination. The instrument was based on the stable and selective cytochrome $\mathrm{c}$ nitrite reductase (ccNiR) from Desulfovibrio desulfuricans (ATCC 27774), which has both high turnover and heterogeneous electron transfer rates. This biological element performs the fast six electron reduction of nitrite to ammonia. This biosensor had $120 \mathrm{nM}$ as a limit detectable concentration and keeping a stable response up to two weeks. Other nitrite biosensor was developed by Rosa et al. [25]. It was an optical biosensor based on cytochrome cd1 nitrite reductase, from the aerobic denitrifier Paracoccus pantotrophus, immobilized in controlled pore glass beads. The developed biosensor operates by measuring the optical reflectance of nitrite reductase, which shows spectroscopic changes when nitrite reversibly binds to the reduced form and oxidizes the enzyme. A biosensing device was developed to detect nitrite in water and obtained detection limit of $0.93 \mu \mathrm{M}$ (nitrite concentration lower than the permissible in water imposed by European Community regulations that is $2.2 \mu \mathrm{M}$ ).

A highly sensitive, fast and stable conductimetric enzymatic biosensor for the determination of nitrate in waters was described in Wang et al. [26-27]. Conductimetric electrodes were modified by methyl viologen mediator mixed with nitrate reductase from Aspergillus niger by cross-linking with glutaraldehyde in the presence of bovine serum albumin and Nafion ${ }^{\circledR}$ cation-exchange polymer, allowing retention of viologen mediator. A linear calibration curve in the range of 0.02 and $0.25 \mathrm{mM}$ with detection limits of $0.005 \mathrm{mM}$ nitrate was obtained. When stored in $\mathrm{pH} 7.5$ phosphate buffer, the sensors showed good stability over two weeks. 


\section{Biosensors for pesticides determination}

A pesticide, as defined by the EPA, is any substance or mixture of substances intended for preventing, destroying, repelling, or lessening the damage of any pest [28]. Of all the environmental pollutants, pesticides are the most abundant, present in water, atmosphere, soil, plants, and food [3].

Pesticides (insecticides, fungicides and herbicides) are used worldwide due to their wide range of activity. They are released intentionally into the environment and, through various processes, end up contaminating it. The presence of pesticide residues and metabolites in food, water and soil currently represents one of the major issues in environmental chemistry research [29]. Due to their increasing use in agriculture, pesticides are among the most important environmental pollutants. So, the continuous monitoring for low pesticide levels in food, water, and air has become a key activity in respect to human health [30].

Three of the main classes of pesticides that pose a serious problem are organophosphates (OPs), organochlorines and carbamates. OPs are usually esters, amides or thiol derivatives of phosphoric, phosphonic or phosphinic acids. These compounds commonly used includes parathion, malathion, methyl parathion, chlorpyrifos, diazinon, dichlorvos, phosmet, fenitrothion, tetrachlorvinphos and azinphos methyl [8].

While pesticides are associated with many health effects, there is a lack of monitoring data on these contaminants. Traditional chromatographic methods, as High Performance Liquid Chromatography (HPLC), are effective for the analysis of pesticides in the environment, but have limitations and prevent adequate monitoring [31]. Due to the restrictions in conventional methodologies, the development of biosensors for direct and indirect pesticide detection is of particular interest.

Different types of pesticides used in food production can accumulate in fatty tissue in animals - including humans, while the excessive use of fertilizers contaminates ground water with nitrates, nitrites and phosphates. The majority of the insecticides used are acetylcholinesterase (AChE) inhibitors, 55\% of them belong to the group of organophosphates and $11 \%$ to carbamates, whereas the others are pyrethroids, chlorinated hydrocarbons or other insecticides [32]. The acetylcholinesterase (EC 3.1.1.7) catalysed hydrolysis of acetylthiocholine generates the electroactive product thiocholine. The current of its oxidation is recorded amperometrically at a potential of $+0.80 \mathrm{~V} / \mathrm{SCE}[33]$.

As mentioned, applied to the monitoring of pesticides in the environment and in many foods, the biosensors typically employ the enzyme acetylcholinesterase, monitoring the occurrence of enzymatic inhibition by organophosphates and carbamates, as these chemical compounds bind to the active center of the enzyme, preventing the hydrolysis reaction of acetylcholine into choline and acetate [1].

For the detection of herbicides such as phenyl urea and triazines, which inhibit photosynthesis, biosensors have been designed with membrane receptors of thylakoid and chloroplasts or complete cells such unicellular alga, for which mainly amperometric and optical transductors 
have been employed [10]. Furthermore, enzymes like cholinesterase (AChE, BChE), organophosphorus-hydrolase (OPH), and urease are used in the design of electrochemical biosensors for pesticides detection. These cholinesterase enzymes have different substrates: AChE preferentially hydrolyzes acetyl esters, such as acetylcholine, whereas BChE hydrolyzes butyrylcholine.

A great number of research studies report the development of biosensors for detecting pesticides based on AChE enzymatic inhibition as shown in Table 2.

\begin{tabular}{|c|c|c|c|c|}
\hline Biological component & Transductor & Analyte & $\begin{array}{c}\text { Limit } \\
\text { detection }\end{array}$ & Reference \\
\hline $\begin{array}{l}\text { AChE immobilized on } \\
\text { multiwalled carbon } \\
\text { nanotubes }\end{array}$ & Amperometry & Carbaryl & $4.0 \mu \mathrm{M}$ & [34] \\
\hline $\begin{array}{l}\text { AChE-choline oxidase on } \\
\text { a gold-platinum } \\
\text { bimetallic nanoparticles }\end{array}$ & $\begin{array}{c}\text { Electrochemical impedance } \\
\text { spectroscopy }\end{array}$ & $\begin{array}{l}\text { Paraoxon ethyl, } \\
\text { aldicarb and sarin }\end{array}$ & $\begin{array}{c}\text { 150-200nM, } \\
40-60 \mu \mathrm{M} \text { and } \\
\text { 40-50nM }\end{array}$ & [35] \\
\hline $\begin{array}{c}\text { AC1.W2.R1/ACCHE } \\
\text { sensors with the help of } \\
\text { Biosensor Toxicity } \\
\text { Analyzer }\end{array}$ & Amperometry & $\begin{array}{l}\text { Residual pesticides } \\
\text { (organophosphorous } \\
\text { and carbamate) on } \\
\text { cotton }\end{array}$ & - & [36] \\
\hline $\begin{array}{l}\text { AChE immobilized on } \\
\text { polyaniline and } \\
\text { multiwalled carbon } \\
\text { nanotubes }\end{array}$ & Chronoamperometry & $\begin{array}{l}\text { Carbaryl and } \\
\text { methomyl }\end{array}$ & around $10 \mu \mathrm{M}$ & [30] \\
\hline
\end{tabular}

Table 2. Biosensors used in pesticides detection based on the inhibition of enzymatic activities.

Sassolas et al. [37] had developed a review of biosensors for pesticide detection. The authors discussed that the molecular imprinted polymers (MIPs) are innovative affinity-based recognition elements that are exploited for the development of environmental sensors. MIPs have been used as artificial recognition elements of biosensors for pesticide detection. These synthetic materials can mimic the function of biological receptors but with less stability constraints and can provide high sensitivity and selectivity while maintaining excellent thermal and mechanical stability. In this context, Jenkins et al. [38] had constructed a pesticide sensor with detection limits less than 10ppt and a response time of less than $15 \mathrm{~min}$.

\section{Biosensor applications in the food industry}

The food industry needs suitable analytical methods for process and quality control. The determination of chemical and biological contaminants in foods is of paramount importance to the health of food because, unlike the contamination of a physical nature, they cannot be 
displayed. Apart from a few important analytes, such as sugars, alcohols, amino acids, flavours and sweeteners, food applications mainly focus on the determination of contaminants. Therefore, it is necessary to invest in the development of biosensors to the analysis of the quality of food, since they have proven to be an extremely viable alternative to traditional analytical techniques such as chromatography. However, very few biosensors play a prominent role in food processing or quality control. Considerable effort must be made to develop biosensors that are inexpensive, reliable, and robust enough to operate under realistic conditions [39].

The potential uses of biosensors in agriculture and food transformation are numerous and each application has its own requirements in terms of the concentration of analyte to be measured, required output precision, the necessary volume of the sample, time required for the analysis, time required to prepare the biosensor or to reuse it and cleanliness requirements of the system [9].

In the area of food the interest in the development of biosensors mainly focuses on analysis of food security (detection of compound contaminants, allergens, toxins, pathogens, and additives etc.) Food composition and online process control (Table 3) [40].

\begin{tabular}{lll}
\hline \multicolumn{2}{c}{ Food safety } \\
\hline Xenobiotic compounds & Bacterial toxins: & Pathogenic microorganisms: \\
- Additives & $\bullet$ Mycotoxins & $\bullet$ Virus \\
- Drugs & $\bullet$ Marine Toxins & $\bullet$ Bacteria \\
- Pesticides and fertilizers & & - Protozoa \\
- Other contaminants: dioxins, PCB's, & \\
PAH's, heavy metals and biotoxins & \\
\hline
\end{tabular}

\begin{tabular}{ll}
\hline & Food quality \\
\hline Composition of food: & Lifetime: \\
- Sugars & - Polyphenols and fatty acids (rancid) \\
- Amino acids & - Sugars and organic acids (maturation) \\
- Alcohols & - Biogenic Amines (index freshness) \\
- Organic acids & - Aliina (garlic and onions) \\
- Cholesterol & \\
\hline
\end{tabular}

Process control

- Sugars (fermentation and pasteurization) - Amino acids (fermentation)

- Lactic acid (cheese production) - Alcohols (fermentation)

Other applications

- GMO's • Animal Reproductive Cycle

Table 3. Main areas applying biosensors technologies in food industry [40].

Quality control is of paramount importance in food and beverage industries. In food and fermentation processes, quick and reliable analytical methods are required to analyze sugars like glucose, fructose and sucrose for better process efficiency and economy Also, the recent demands for high quality food products to meet the customer needs have opened up newer 
and improved sensor technologies that are coupled with production processes for quality control and consumer assurance.

The concept of food safety involves ensuring the production and marketing of harmless food, and by that way ensure the health of the consumer. The quantity and types of food additives incorporated into food products are regulated by the legislation of each country, their detection and quantification are important to prevent fraud and malpractice by manufacturers, allergies and other adverse effects to determined groups of the population [10]. Because of this, special attention has been given the way to detect the presence of contaminants, such as residues of heavy metals and components antinutritional.

On the other hand, foods can naturally present anti-nutritional compounds that can generate disorders in the consumer, given that they hinder absorption and metabolize distinct nutrients causing them to have a deficiency. Antinutritional components (oxalate and glycoalkaloids) or allergen (gluten) can be contained naturally in foods. First mentioned are mostly detected by enzymatic amperometric biosensors, while for allergens are described imunosensors [40]. Table 4 presents some examples of biosensors used in the detection of anti-nutrients.

\begin{tabular}{cccc}
\hline Biological component & Transductor & Analyte & Reference \\
\hline $\begin{array}{c}\text { oxalate oxidase immobilized } \\
\text { on chitosan }\end{array}$ & Potenciometric & Oxalate & {$[41]$} \\
\hline $\begin{array}{c}\text { oxalate oxidase and peroxidase } \\
\text { oxalate oxidase immobilized } \\
\text { on gold nanoparticles }\end{array}$ & Amperometry & Oxalate in urine & {$[42]$} \\
\hline$\beta$-glucosidase & Amperometry & Oxalate & {$[43]$} \\
\hline Peroxidase & Potenciometric & amygdalin & {$[44]$} \\
\hline
\end{tabular}

Table 4. Biosensors used in anti-nutrients detection.

Oxalic acid is of great importance in food industries and clinical analysis. An increase in oxalate excretion through urine indicates hyperoxaluria, renal failure, kidney lesions and pancreatic insufficiency. The ingestion of a large quantity of food rich in oxalic acid can cause loss of calcium in the blood as well as injury to the kidneys $[43,46]$. Many methods have been recommended for oxalate determination in clinical laboratory analyses but some of them are time-consuming (as chromatographic and spectrophotometric) while some others need a chemically pre-treated sample [42].

Cyanogenic glycosides, such as amygdalin, are found in a wide variety of plants. Although cyanogenic glycosides are not toxic as it is, cyanide liberated from them as a result of hydrolysis has acute toxicity as is well known [45]. The design of a simple D-amygdalin biosensor is important for its applications, namely in the analytical monitoring of this cyanogenic glycoside. Several dried fruits like bitter almonds or kernels etc. contain amygdalin. Cyanoglycosides yield glucose, benzaldehyde and hydrocyanic acid when hydrolysed in vitro by mineral acids or in vivo by enzymes. Unexpectedly, efluents of food and feed production can also contain cyanide [44]. 


\subsection{Commercially available biosensors for food industry}

Despite the large number of publications on biosensors used in food analysis, only a few systems are commercially available (Table 5). Among some limitations that must be overcome are the limited lifespan of biological components, mass production, as well as convenience in handling. However, these problems can be managed in a near future, since the biosensors provide unique solutions for food analysis in terms of specificity and time saving [47].

\begin{tabular}{|c|c|c|}
\hline Company & Biosensor & Country \\
\hline Oriental electric & Fish deterioration tracking & China \\
\hline $\begin{array}{l}\text { Massachusetts Institute of } \\
\text { Technology }\end{array}$ & Detection of Escherichia coli 0157:H7 in lettuce (Canary) & USA \\
\hline $\begin{array}{l}\text { Michigan State University's } \\
\text { Electrochemical Biosensor }\end{array}$ & $\begin{array}{l}\text { Detection of Escherichia coli O157:H7 and Salmonella in } \\
\text { meat products in USA }\end{array}$ & USA \\
\hline Georgia Research Tech Institute & $\begin{array}{l}\text { Detection of Salmonella and Campylobacter } \\
\text { in pork industry }\end{array}$ & USA \\
\hline Naval Research Laboratory & $\begin{array}{l}\text { Detection of Staphylococcal enterotoxin B and Botuminum } \\
\text { toxin A in tomatoes, sweet corn, beans and mushrooms }\end{array}$ & USA \\
\hline $\begin{array}{l}\text { Universitat Autònoma de Barcelona } \\
\text { in collaboration with CSIC }\end{array}$ & Detection of atrazine traces & Spain \\
\hline Molecular Circuitry Inc. & $\begin{array}{l}\text { Escherichia coli 0157, Salmonella, Listeria and } \\
\text { Campylobacter }\end{array}$ & USA \\
\hline Research International & $\begin{array}{l}\text { Proteins, toxins, virus, bacteria, spores and fungi } \\
\text { (simultaneous analysis) }\end{array}$ & USA \\
\hline Universal Sensors & $\begin{array}{l}\text { Ethanol, methanol, glucose, sucrose, lactose, L-aas, } \\
\text { glutamine, ascorbic acid and oxalate }\end{array}$ & USA \\
\hline Texas Instruments Inc. & Penaut Allergens, antibiotics & USA \\
\hline Yellow Springs Instruments Co & $\begin{array}{l}\text { Glucose, sucrose, lactose, L-lactate, galactose, L-glutamate, } \\
\text { ethanol, } \mathrm{H}_{2} \mathrm{O}_{2} \text {, starch, glutamine and choline }\end{array}$ & USA \\
\hline Affinity Sensors & Staphylococcus aureus and cholera toxin & UK \\
\hline Ambri Limited & Pathogens such as Salmonella e Enterococcus & USA \\
\hline Biacore $A B$ & $\begin{array}{l}\text { Water soluble vitamins, chemical veterinary residues and } \\
\text { mycotoxins }\end{array}$ & Sweden \\
\hline BioFutura Srl & Glucose, fructose, malic acid and lactic acid (fermentation) & Italy \\
\hline Biomerieux & Microorganisms & France \\
\hline Biosensor Systems Desing & Microorganisms and toxic substances & USA \\
\hline Biosensores S.L. & Toxic substances & Spain \\
\hline Chemel AB & Glucose, sacarose, ethanol, methanol and lactose & Sweden \\
\hline IVA Co Ltd & Heavy metals & Rusia \\
\hline Motorola & Microorganisms and GMO's & Japan \\
\hline Inventus Bio Tec & Ascorbic acid & Germany \\
\hline
\end{tabular}

Table 5. Commercial biosensors for food industry. Modified from [40,47]. 


\section{Biosensors for benzoic acid detection}

The concept of food security implies the production and marketing of food products that offer no risk to consumer health. The use of additives has become an increasingly common practice in the food industry seeking greater lifetime favoring storage and long distance transport [48].

Due to the growing demand for processed food, the use of preservatives has been gaining importance in modern food technology. Benzoic acid as well as salts, benzoates $\mathrm{Na}$ and $\mathrm{K}$, are among the most widely used preservatives to inhibit microbial growth, depending on the costbenefit [49]. Benzoates constitute very important group of food additives to protect the consumer from microbiological risks of some bacteria, fungi and yeasts which may be responsible for poisoning [50].

Given the wide use of benzoic acid and its salts (benzoates) as preservatives in the food industry, detection and quantification of these are of great importance in controlling product quality in order to prevent fraud and improper manufacturing practices, considering the possible adverse effects those including preservatives, exacerbation of symptoms of chronic rhinitis, asthmatic reactions, hyperactivity in children, genotocixidade, clastogenicity and mutagenicity (in human lymphocytes) [51-54]. Furthermore benzoates may undergo decarboxylation in the presence of ascorbic acid under certain conditions to form benzene beverages [55-56].

Although considered safe for health, studies suggest that the consumption of these preservatives is related to a number of adverse health effects, especially in children and susceptible people. The acute toxicity is low benzoates. However, cases of urticaria, rhinitis, asthma and anaphylaxis have been reported after oral, dermal or inhalation. In sensitive people, even at doses lower than $5 \mathrm{mg} / \mathrm{kg}$ may cause immunologic reactions do not contact (pseudo-allergy) [50].

In the case of food additives, it is important to note that the toxicity or the benefits depend on the extent to which this food components has adsorption, metabolism and excretion affected as a whole, since there are synergistic interactions among them, the limits for human consumption can be changed [10]. Some studies have reported cases of allergic cross-reactions benzoates and other additives such as sunset yellow, for example [53].

Aiming to make the analysis of benzoates in food, faster, cheaper and simpler, there has been development of various methodologies described in the literature in terms of biosensors as promising alternatives to conventional methods (Table 6). Thus the immense development opportunities and market potential, has driven research analysis methods to the area of food in terms of biosensors [65].

Amperometric biosensors based on enzymes have emerged in the last decade, with the possibility of very promising application in the food and beverage industry. These devices are usually highly selective, sensitive, relatively inexpensive and easy to handle system integration and continuous analysis. Successful application of these sensors for industrial purposes, however, requires a sensor design which meets the specific needs monitoring of the target 


\begin{tabular}{|c|c|c|}
\hline Biosensor/principle & Detection range/sample & References \\
\hline $\begin{array}{l}\text { Mushroom tissue homogenate/ enzyme } \\
\text { inhibition }\end{array}$ & 25-100 uM (non-alcoholic) & [57] \\
\hline PPO-PANI/enzyme inhibition & $0.0366 \mathrm{mg} / \mathrm{L}$ (non-alcoholic) & [58] \\
\hline PPO-PANI- Pan/enzyme inhibition & $\begin{array}{c}2 \times 10^{-7} \mathrm{M} \text { (milk, yogurth andnon-alcoholic } \\
\text { beverages) }\end{array}$ & [59] \\
\hline PPO-Teflon/grafite/enzyme inhibition & $\begin{array}{c}9.0 \times 10^{-7} \mathrm{M} \text { (mayonnaiseand non-alcoholic } \\
\text { beverages) }\end{array}$ & {$[60]$} \\
\hline $\begin{array}{l}\text { Carbon Electrode modified with PPO- } \\
\text { nano-CaCO3/enzyme inhibition }\end{array}$ & $\begin{array}{c}5.6 \times 10^{-7}-9.2 \times 10^{-5} \mathrm{M} \text { (yogurth, and non- } \\
\text { alcoholic beverages) }\end{array}$ & [61] \\
\hline $\begin{array}{l}\text { Glassy Carbon Electrodemodified with } \\
\text { PPO/CaHPO }{ }_{4} \text { enzyme inhibition }\end{array}$ & $\begin{array}{c}119.6-132 \mathrm{mg} / \mathrm{L} \text { (non-alcoholic beverages, } \\
\text { mayonnaise) }\end{array}$ & [62] \\
\hline $\begin{array}{l}\text { PPO-Gel made of Titanium modifiedwith } \\
\text { carbon nanotubes /enzyme inhibition }\end{array}$ & $0.03 \mathrm{mM}-1.06 \mathrm{mM}$ (non-alcoholic beverages) & [63] \\
\hline
\end{tabular}

Table 6. Biosensors for detection benzoate/benzoic acid in food samples.

analyte in the particular application, since each individual application requires different operating conditions and characteristics of sensor [64].

Addition of enzyme activity, enzyme inhibition can also be used as analytical signal to be monitored in biosensors thus the activity is measured before and after inhibition promoted by a specific inhibitor in a given time range [66]. The percentage inhibition of enzyme is sustained by quantitatively related to the concentration of the inhibitor [67]. Generally, biosensors developed for detection of benzoic acid in food, are based on the principle of enzyme inhibition [67].

The characteristics of biosensors are dependent biological element of the recognition and signal transducer used as well as the communication between these two elements, which means that although promising, have limitations and drawbacks as well as any other methods of analysis [68].

\section{Biosensors for heavy metals}

Heavy metals are the most dangerous environmental contaminants, which present a serious threat to human health, even in trace quantities. Contamination of soils due to discharge of industrial effluents is one of the most significant problems faced by man. Heavy metals are widely existent in these contaminated environments. For example, many places are considerably polluted with chromium from tannery waste waters. In these areas, chromium exists in 
both the hexavalent and the trivalent forms. The plants grown in such areas can accumulate chromium ions. These ions have certain threshold levels for essential functions of living organism and man, but cause toxic actions if the tolerance levels exceed [69].

Moreover, fertilizer has become one of the polluting sources of heavy metals. So repetitive applications of commercial fertilizers and pesticides continually for agriculture have contributed to a continuous accumulation of heavy metals in soils. The trace metal content of commercial fertilizers is also highly variable, depending mainly on the phosphate rock source and the fertilizer production process. The heavy metals in fertilizer can endanger the human body by the crop containing heavy metals [70-71].

The majority of existing techniques used for trace analysis of heavy metals includes spectroscopic, voltammetric and chromatographic methods, which can detect species at low concentrations or even in single elements. However, all of these traditional methods are generally expensive and can hardly be used for in situ analysis. Recently, the ability to detect heavy metal contaminants using biosensors for in situ analysis has gained much interest [72].

Soldatkin et al. [73] presented by a biosensor composter a differential pair of planar thin-film interdigitated electrodes, deposited on a ceramic pad, (used as a conductometric transducer) together with the three-enzyme system (invertase, mutarotase, glucose oxidase), immobilized on the transducer surface, (used as a bioselective element). The developed biosensor demonstrated the best sensitivity toward ions $\mathrm{Hg}^{2+}$ and $\mathrm{Ag}^{+}$.

Ravikumar et al. [74], designed and applied molecular biosensor for heavy metals, zinc and copper, for use in bioremediation strategies. Bacteria utilize two component systems to sensor change in the environment by multi signal components incluing heavy metals and control gene expression in response to changes in signal molecules.

\section{Conclusions}

The modern environmental and food analysis requires sensitive, accurate, and express methods. The growing field of the biosensors represents an answer to this demand. Unfortunately, most biosensor systems have been tested only on distilled water or buffered solutions, but more biosensors that can be applied to real samples have appeared in recent years. In this context, biosensors for potential environmental and food applications continue to show advances in areas such as genetic modification of enzymes and microorganisms, improvement of recognition element immobilization and sensor interfaces.

\section{Acknowledgements}

The authors thank the financial support of the National Council for Scientific and Technological Development (CNPq), CAPES (Coordination for the Improvement of Higher Level Personnel) and the Foundation for Research of the State of Rio de Janeiro (FAPERJ). 


\section{Author details}

Lívia Maria da Costa Silva ${ }^{1}$, Vânia Paula Salviano dos Santos ${ }^{1}$, Andrea Medeiros Salgado ${ }^{1^{*}}$ and Karen Signori Pereira ${ }^{2}$

*Address all correspondence to: andrea@eq.ufrj.br

1 Laboratory of Biological Sensors, Biochemical Engineering Department, Chemistry School, Technology Center, Federal University of Rio de Janeiro, Ilha do Fundão, Rio de Janeiro, Brazil

2 Laboratory of Food Microbiology, Biochemical Engineering Department, Chemistry School, Technology Center, Federal University of Rio de Janeiro, Ilha do Fundão, Rio de Janeiro, Brazil

\section{References}

[1] Silva LMC, Melo AF, Salgado A.Biosensors for environmental applications, (2011). Environmental Biosensors, Vernon Somerset (Ed.), 978-9-53307-486-3InTech.

[2] Rogers, K. R, \& Gerlach, C. L. Environmental biosensors: A status report, Environ. Sci. Technol. 30 ((1996). , 486-491.

[3] Rodriguez-mozaz, S, \& Marco, M-P. Alda MJL, Barceló D. Biosensors for environmental applications: future development trends, Pure Appl. Chem. (2004). , 2004(76), 723-752.

[4] Rogers, K. R. Recent advances in biosensor techniques for environmental monitoring. Anal. Chim. Acta (2006). , 568, 222-231.

[5] Thévenot, D. R, Toth, K, Durst, R. A, \& Wilson, G. S. Electrochemical biosensors: Recommended definitions and classification, Pure Appl. Chem. 71 ((1999). , 2333-2348.

[6] Korostynska, . , Monitoring of nitrates and phosphates in wastewater: current technologies and further challenges, International Journal on Smart Sensing and Intelligent Systems, v.5, n.1, pp.149-176, 2012

[7] Rai, . , Implications of nanobiosensors in agriculture, Journal of Biomaterials and Nanobiotechnology, v.3, pp. 315-324, 2012

[8] Gahlaut, ., Electrochemical biosensors for determination of organophosphorus compounds: review, Open Journal of Applied Biosensor, v.1, pp. 1-8, 2012

[9] Velasco-garcía, M. N, \& Mottram, T. (2003). Biosensor technology addressing agricultural problems, Biosyst. Eng, 84, , 1-12. 
[10] Cock, L. S. Arenas, AMZ, Aponte, AA. Use of enzymatic biosensor as quality indices: a synopsis of present and future trends in the food industry, Chilean Joural of Agricultural Research (2009 6). , 2009(69), 2-270.

[11] Guilbault GG Montalvo, J. Urea specific enzyme electrode. Journal of the American Chemical Society, (1969). , 91, 2164-2569.

[12] Arnold, MA Glazier, SA Jack. Bean meal as biocatalyst for urea biosensors. Biotechnology Letters, n. 5, (1984). , 6, 313-318.

[13] Takishima, K, Suga, T, \& Mamiya, G. (1988). The structure of jack bean urease. European Journal of Biochemistry, , 175, 151-165.

[14] Panpae, K, Krintrakul, S, \& Chaiyasit, A. Development of a urea potentiometric biosensor based on gelatin-immobilized urease. Kasetsart Journal (Natural Science) (2006). , 2006(40), 74-81.

[15] Chirizzi, D, \& Malitesta, C. Potentiometric urea biosensor based on urease immobilized by an electrosynthesized poly (o-phenylenediamine) film with buffering capability. Sensors and Actuators B: Chemical (2011 1). , 2011(157), 1-211.

[16] Nikoleli, G-P, Nikolelis, D. P, \& Methenitis, C. Construction of a simple optical sensor based on air stable lipid film with incorporated urease for the rapid detection of urea in milk. AnalyticaChimicaActa (2010). , 2010(675), 58-63.

[17] Trivedi, U. B, Lakshminarayana, D, Kothari, I. L, Patel, N. G, Kapse, H. N, Makhija, K. K, Patel, P. B, \& Panchai, C. J. Potentiometric biosensor for urea determination in milk. Sensors and Actuators B, (2009). , 140, 260-266.

[18] Hedayatollah, G, Ahmad, M. R, \& Hossein, E. A conductometric urea biosensor by direct immobilization of urease on Pt electrode. Iranian Journal of Chemistry \& Chemical Engineering, n. 2, (2004). , 23, 55-63.

[19] Vostiar, I, Tkac, J, Sturdik, E, \& Gemeiner, P. Amperometric urea biosensor based on urease and electropolymerized toluidine blue dye as a $\mathrm{pH}$-sensitive redox probe. Bioelectrochemistry, n. 1-2, (2002). , 56, 113-115.

[20] Verma, N, Kumar, R, \& Kumar, M. S. Simple, qualitative cum quantitative, user friendly biosensor for analysis of urea, Advances in Applied Science Research, (2012). , 135-141.

[21] Rodriguez-mozaz, S, Alda, M. J, Marco, M. P, \& Barceló, D. A global perspective: Biosensors for environmental monitoring, Talanta. 65 ((2005). , 291-297.

[22] Cho, S-J, Sasaki, S, Ikebukuro, K, \& Karube, I. A simple nitrate sensor system using titaniumtrichloride and an ammonium electrode, Sensors and Actuators B, (2002). , $85,120-125$.

[23] Moorcroft, M. J. Davis J Compton RG, Detection and determination of nitrate and nitrite: A review. Talanta (2001). , 2001(54), 785-803. 
[24] Silveira, C. M, Gomes, S. P, \& Araújo, A. N. Montenegro MCBSM, Todorovic S, Viana AS, Silva RJC, Moura JJG, Almeida MG, An efficient non-mediated amperometric biosensor for nitrite determination, Biosensors and Bioelectronics, (2010). , 25, 2026-2032.

[25] Rosa, C. C, Cruz, H. J, Vidal, M, \& Oliva, A. G. Optical biosensor based on nitrite reductaseimmobilised in controlled pore glass, Biosensors \& Bioelectronics, (2002). , 17, 45-52.

[26] Wang, X, Dzyadevych, S. V, Chovelon, J. M, Jaffrezic-renault, N, Ling, C, \& Siqing, X. Conductometric nitrate biosensor based on Methyl viologen/Nafion®/Nitrate reductaseinterdigitated electrodes. Talanta 69 ((2006). , 450-455.

[27] Wang, X, Dzyadevych, S. V, Chovelon, J. M, Jaffrezic-renault, N, Ling, C, \& Siqing, X. Development of conductometric nitrate biosensor based on Methyl viologen/ Nafion ${ }^{\circledR}$ composite film, Electrochem. Commun. 8 ((2006). , 201-205.

[28] Tothill, L. E. Biosensors developments and potential applications in the agricultural diagnosis sector. Comput. Electron. Agric. 30 ((2001). , 205-218.

[29] Mostafa, G. A. Electrochemical biosensors for the detection of pesticides, The Open Electrochemistry Journal, (2010). , 2, 22-42.

[30] Cesarino, I, \& Moraes, F. C. Lanza MRV, Machado SAS, Electrochemical detection of carbamate pesticides in fruit and vegetables with a biosensor based on acetylcholinesteraseimmobilised on a composite of polyaniline-carbon nanotubes, Food Chemistry, (2012). , 135, 873-879.

[31] Van Dyk, J. S. Pletschkeb. Review on the use of enzymesfor the detection of organochlorine, organophosphate and carbamatepesticides in the environment. Chemosphere, Elmsford, (2011). , 82, 291-307.

[32] Schulze, H, Scherbaum, E, Anastassiades, M, Vorlova, S, Schmid, R. D, \& Bachmann, T. T. Development, validation, and application of an acetylcholine esterase biosensor test for the direct detection of insecticide residues in infant food. Biosensors and Bioelectronics (2002). , 2002(17), 1095-1105.

[33] Stoytcheva, M, Zlatev, R, Ovalle, M, Velkova, Z, Gochev, V, \& Vladez, B. Electrochemical biosensors for food quality control, (1998).

[34] Cai, J, \& Du, D. A disposable sensor based on immobilization of acetylcholinesterase to multiwall carbon nanotube modified screen-printed electrode for determination of carbaryl, Journal of Applied Electrochemistry, n. 9, (2008). , 38, 1217-1222.

[35] Upadhyay, S, Rao, G. R, Sharma, M. K, Bhattacharya, B. K, Rao, V. K, \& Vijayaraghavan, R. Immobilization of acetylcholineesterase-choline oxidase on a gold-platinum bimetallic nanoparticles modified glassy carbon electrode for the sensitive detection of organophosphate pesticides, carbamates and nerve agents, Biosens. Bioelectron., n.4, (2009). , 25, 832-838. 
[36] Hassan SZU, Militky J,Acetylcholinesterase based detection of residual pesticides on cotton, American Journal of Analytical Chemistry, (2012). , 3, 93-98.

[37] Sassolas, A, Prieto-simón, B, \& Marty, J-L. Biosensors for pesticide detection: new trends, American Journal of Analytical Chemistry, (2012). , 3, 210-232.

[38] Jenkins, A. L, Yin, R, \& Jensen, J. L. Molecularly imprinted polymer sensors for pesticide and insecticide detection in water, Analyst, n. 6, (2001). , 126, 798-802.

[39] Luong JHT, Groom CA, Male KB.The potential role of biosensors in the food and drink industries. Biosens. and Bioelectron. (1991). , 1991(6), 547-554.

[40] Rumayor, V. G, Iglesias, E. G, Galán, O. R, \& Cabezas, L. G. Aplicaciones de biosensores en la industria agroalimentaria. Madrid: Comunidad de Madrid y la UniversidadComplutense de Madrid; (2005).

[41] Benavidez, T. E, Alvarez, C, \& Baruzzi, A. M. Physicochemical properties of a mucin/ chitosan matrix used for the development of an oxalate biosensor. Sensors and Actuators B (2010). , 2010(143), 660-665.

[42] Milardovic, S, \& Kerekovic I, . . A novel biamperometric biosensor for urinary oxalate determination using flow-injection analysis. Talanta 2008 (77) 222-228.

[43] Pundir, C. S, \& Chauhan, N. Rajneesh, Verma M, Ravi. A novel amperometric biosensor for oxalate determination using multi-walled carbon nanotube-gold nanoparticle composite. Sensors and Actuators B (2011). , 2011(155), 796-803.

[44] Merkoçi, A, Braga, S, Fábregas, E, \& Alegret, S. A potentiometric biosensor for Damygdalin based on a consolidated biocomposite membrane. AnalyticaChimicaActa (1999). , 1999(391), 65-72.

[45] Tatsuma, T, Tani, K, Ogawa, T, \& Oyama, N. Interference-based amygdalin sensor with emulsin and peroxidase. SensorsandActuators B (1998). , 1998(49), 268-272.

[46] Fiorito, P. A, \& Cordoba, S. I. Otimized Multilayer oxalate Biosensor, Talanta, (2004). , 62, 649-654.

[47] Furtado, R. F. Dutra RAF, Alves CR, Pimenta MGR, Guedes MIF. Aplicações de Biossensores na Análise da Qualidade de Alimentos. Fortaleza: EMBRAPA; (2008). novembro. Report (1677-1915), 1677-1915.

[48] Kochana, J, Kozak, J, Skrobisz, A, \& Wozniakiewicz, M. Tyrosinase biosensor for benzoic acid inhibition-based determination with the use of a flow-batch monosegmented sequential injection system. Talanta. (2012). December; 96(2).

[49] Mello, L. D, \& Kubota, L. T. Review of the use of biosensors as analytical tools in the food and drink industries. Food Chemistry. (2002). dezembro 2; 77: , 237-256. 
[50] Gustavsson, E, Bjurling, P, \& Sternesjö, A. Biosensor analysis of penicillin G in milk based on the inhibition of carboxypeptidase activity. Analytica Chimica Acta. (2002). julho 02;(468): , 153-159.

[51] Leonard, P, Hearty, S, Brennan, J, Dunnea, L, Quinn, J, Chakraborty, T, et al. Advances in biosensors for detection of pathogens in food and water. Enzyme and Microbial Technology. (2003). agosto;(32): , 3-13.

[52] Mutlu, M. Biosensors in Food Processing, Safety, and Quality Control. 1st ed. Mutlu M, editor.: CRC Press; (2010).

[53] Metcalfe, D. D, Sampson, H. A, \& Simon, R. A. Food Allergy: Adverse Reactions to Foods and Food Additives. 4th ed. Malden: John Wiley \& Sons; (2009).

[54] Shan, D, Li, Q, Xue, H, \& Cosnier, S. A highly reversible and sensitive tyrosinase inhibition-based amperometric biosensor for benzoic acid monitoring. Sensors and Actuators B: Chemical. (2008). julho; I(134): , 1016-1021.

[55] Csöoregi, E, Gáspñr, S, Niculescu, M, Mattiasson, B, \& Schuhmann, W. Physics and chemistry basis of biotechnology Amsterdan: Springer Netherlands; (2002).

[56] Viswanathan, S, Radecka, H, \& Radecki, J. Electrochemical biosensors for food analysis. MonatsheftefürChemie. (2009). Abril; I(140): , 891-899.

[57] Sezgintürk, M. K, Göktug, T, \& Dinçkaya, E. Detection of Benzoic Acid by an Amperometric Inhibitor Biosensor Based on Mushroom Tissue Homogenate. Food Technology and Biotechnology. (2005). setembro; IV(43): , 329-334.

[58] Li, S, Tan, Y, Wang, P, \& Kan, J. Inhibition of benzoic acid on the polyaniline-polyphenol oxidase biosensor. Sensors and Actuators B: Chemical. (2010). agosto; I(144): , $18-22$.

[59] Shan, D, Shi, Q, Zhu, D, \& Xue, H. Inhibitive detection of benzoic acid using a novel phenols biosensor based on polyaniline-polyacrylonitrile composite matrix. Talanta. (2007). fevereiro; I(72): , 1767-1772.

[60] Morales, M. D, Morante, S, Scarpa, A, González, M. C, Reviejo, A. J, \& Pingarrón, J. M. Design of a composite amperometric enzyme electrode for the control of the benzoic acid content in food. Talanta. (2002). Abril; II(57): , 1189-1198.

[61] Shan, D, Li, Q, Xue, H, \& Cosnier, S. A highly reversible and sensitive tyrosinase inhibition-based amperometric biosensor for benzoic acid monitoring. Sensors and Actuators B: Chemical. (2008). julho; II(132): , 1016-1102.

[62] López MSPLópez-Ruiz B. Inhibition Biosensor Based on Calcium Phosphate Materials for Detection of Benzoic Acid in Aqueous and Organic Media. Electroanalysis. (2011). outubro; I(23): , 264-271. 
[63] Kochana, J, Kozak, J, Skrobisz, A, \& Wozniakiewicz, M. Tyrosinase biosensor for benzoic acid inhibition-based determination with the use of a flow-batch monosegmented sequential injection system. Talanta. (2012). December; 96(2).

[64] Gardner, L. K, \& Lawrence, G. D. Benzene Production from Decarboxylation of Benzoic Acid in the Presence of Ascorbic Acid and a Transition-Metal Catalyst. Journal of Agricultural and Chemistry Food. (1993). maio; 41(5): , 693-695.

[65] Moutinho IDLBertges LG, Assis RVC. Prolonged use of the food dye tartrazine $\left(F D \& C\right.$ yellow $\left.n^{\circ} 5\right)$ and its effects on the gastric mucosa of Wistar rats. Brazilian Journal of Biology. (2007). fevereiro; 67(1): , 141-145.

[66] Stadle, R. H, \& Lineback, D. R. Process-Induced Food Toxicants: Occurrence, Formation, Mitigation, and Health Risks. 1st ed. New Jersey: John Wiley \& Sons; (2008).

[67] Marques PRBdOYamanaka H. Biossensores baseados no processo de inibição enzimática. Química Nova. (2008). setembro 9; VII(31): , 1791-1799.

[68] Ene, C. P, \& Diacu, E. High-performance liquid chromatography method for the determination of benzoic acid in beverages. U.P.B. Sci. Bull. (2009). , 81-88.

[69] Ntihuga, J. N. Biosensor to detect heavy metals in waste water. Proceedings from the International Conference on Advances in Engineering and Technology, (2006). , 159-166.

[70] Atafar, Z, Mesdaghinia, A, Nouri, J, Homaee, M, Yunesian, M, Ahmadimoghaddam, M, \& Mahvi, A. H. Effect of fertilizer application on soil heavymetal concentration, Environ. Monit. Assess., (2010). , 160, 83-89.

[71] Frost, H. L. Jr LHK, Trace metal concentration in durum wheat from application of sewage sludge and commercial fertilizer, Advances in Environmental Research, (2000). , 4, 347-355.

[72] Castillo, J, Gáspár, S, Leth, S, Niculescu, M, Mortari, A, Bontidean, I, Soukharev, V, Dorneanu, S. A, Ryabov, A. D, \& Csoregi, E. Biosensors for life quality: Design, development and applications, Sensors and Actuators B: Chemical, n.2, (2004). , 102, 179-194.

[73] Soldatkin, O. O, Kucherenko, I. S, Pyeshkova, V. M, Kukla, A. L, Affrezic-renault, N, Skaya, A. V, Dzyadevych, S. V, \& Soldatkin, A. P. Novel conductometric biosensor based on three-enzyme system for selective determination of heavy metal íons. Bioelectrochemistry (2012).

[74] Ravikumar, S, Ganesh, I, Yoo, I, \& Hong, S. H. Construction of a bacterial biosensor for zinc and copper and its application to the development of multifunctional heavy metal adsorption bactéria. Process Biochemistry (2012). , 2012(47), 758-765. 